\title{
Scientific research and training in biotechnology in Latin America and the Caribbean: the UNU/BIOLAC experience
}

\author{
Camilo Daza \\ Carretera Nacional Hoyo de la Puerta Baruta Instituto de Estudios Avanzados, IDEA Edificio Bolivar, Planta Baja Venezuela \\ Tel.: (58-2) 9621644/ 9621605 Fax: (58-2) 9621120 \\ mail: unu@reacciun.ve cdaza@reacciun.ve \\ Home page: http:/ / zeus.ivic.ve/ biolac
}

It is well known that the number of researchers in Biotechnology in Latin America and the Caribbean is too small to cope with the needs of research and to successfully confront the number of short and long-term problems.

The United Nations University created its Biotechnology Program for Latin America and the Caribbean, UNU/BIOLAC, and the results of the efforts aiming to the promotion of a shared sense of direction within the region's scientific community are presented and discussed herein.

The United Nations University and its Biotechnology Program

Aiming towards the promotion of international understanding, the United Nations sponsored the creation of an academic institution that would help developing countries in their strugglefor a better and more peaceful life.

Under the initiative of the Secretary General at that time, $\mathrm{Mr}$. U. Thant, The United N ations University, UNU, was created in 1973, beginning its activities in 1975. In 1988, under the Rectorship of Prof. Heitor Gurgulino de Souza, with the income of two out of the seven million dollars paid from the ten million dollars pledged by the Venezuelan Government to the Universities Endowment Fund, the UNU created the Biotechnology Program for Latin A merica and the Caribbean, UNU/BIOLAC. Since then, it has received additional contributions from the Governments of Canada and Peru. With those limited resources, basically the income of the two million dollars pledged by the Venezuelan Government the
UNU/BIOLAC Program has been concentrating on three areas recommended by its Scientific Advisory Committee. These are Diagnostics and Vaccines for Human and Animal Disease, Plant Genetics Engineering, and Microorganisms of Industrial Interest

The goal of the UNU/BIOLAC Program is essentially to promote through its actions, a shared sense of direction that might have an impact on intellectual development in the region, specifically in Biotechnology. The Program's strategy is to develop human resources in the scientific community with the collaboration of well known scientists and institutes al ready established in the region and enlarge the capacity of scientific research in the region by integrating those human resources in research networks.

The Program has a General Coordinator located in Caracas Venezuela, who is assisted by the Scientific Coordinators of the Research Networks, and two Associated Experts. It is important to stress that the overheads expenditure of the Program only reaches $10 \%$ of its budget, approximately $57 \%$ goes into training and fellowships leaving the rest for the research activities of the Networks.

\section{Development of human resources}

The UNU/ BIOLAC Program began its activities in 1989, developing human resources in the region by granting short term fellowships, supporting high level academic courses with the collaboration of Centers of Excellence in the region, and by establishing research networks, see Table 1.

Table 1. Mechanisms followed by UNU/ BIOLAC to fulfill its objectives

\begin{tabular}{|l|}
\hline Courses \\
\hline Fellowships \\
\hline Research Networks \\
\hline
\end{tabular}

The scheme intends to strengthen the region's academic institutions, and to assist the career development of scholars and scientists, particularly young researchers. It also aims to promote an understanding of complex problems in their global context, the development of analytical skills and the ability to conduct and direct research.

The results presented here are those found in the Program's data bank and covers the eight year period since the Program was created, including all the participants of the training fellowships and courses sponsored by the Program.

\section{Training courses}

The Program uses the human resources already established in the region, to improve the scientific skills of others that would directly benefit from the Program by taking advantage of the training programs and courses offered.

To run the highly specialized courses, many institutions were visited in order to identify qualified academic institutions that were willing to serve as centers for the Program in order to fulfil its task in the region.

The Program annually offers an average of five international two-week training courses. The support given to each course includes the support of international participants, covering $75 \%$ of the register.

During a seven-year period, forty courses were held in the region sponsored by UNU/BIOLAC. Table 2 shows the countries that hosted those 40 courses. 
Table 3 shows the list of all the courses lectured over the seven-year period.

Table 2. Courses per country

\begin{tabular}{|l|l|}
\hline Argentina & 5 \\
\hline Brazil & 2 \\
\hline Cuba & 2 \\
\hline Chile & 1 \\
\hline Guatemala & 5 \\
\hline Mexico & 12 \\
\hline Venezuela & 13 \\
\hline Total & 40 \\
\hline
\end{tabular}

\section{Fellowships}

In order to accomplish its goals, the Program uses the same methods as other international academic institutions that grant fellowships. The candidates for a short-term training fellowship have to submit a form stating their scientific background including research experience and their areas of interest, giving reasons why they are interested in the Program. In addition, the applicant has to submit a supporting letter from the institution where he or she is currently working. This is to guarantee that the institution is interested in training the candidate and to insure that he or she is an active employed scientist. Finally, the candidate has to be accepted by the laboratory where the training will take place. This avoids the possibility of converting the Program into a placement office. Scientists have discovered that there are many possibilities for collaborative projects that can be developed within Latin America and the Caribbean.

Whenever possible, we interview the candidates at their working place in order to have a closer look at their capacity and interest. In most cases we complete the data with what we call a "Site Visit Report", which allows us to focus our attention in the institution where the candidate is actually working. By doing so, we have a better knowledge of the institutional capacities in the region.

Table 3. Courses lectured between 1990 and 1997

\begin{tabular}{|c|c|c|}
\hline Name of the Course & Date & Organizer \\
\hline $\begin{array}{l}\text { "Diagnostic Methods of Human } \\
\text { Disease" }\end{array}$ & 11-23Nov. 19901.V.I.C.-Venezuela & Dr. Manue Rieber \\
\hline $\begin{array}{l}\text { "Scaling up of Biotechnological } \\
\text { Processes" }\end{array}$ & $\begin{array}{l}\text { 12-30Nov. } 1990 \text { CEINGEBI- } \\
\text { UNAM Mexico }\end{array}$ & Dr. Rodolfo Quintero \\
\hline $\begin{array}{l}\text { "Engineering of Biological } \\
\text { Reactions an Processes" }\end{array}$ & $\begin{array}{l}\text { 13-24May 1991ICAITI - } \\
\text { Guatemala }\end{array}$ & Dr. Carlos Rolz \\
\hline $\begin{array}{l}\text { "New Production Technologies } \\
\text { and Control of Pertussis Vaccine" }\end{array}$ & $\begin{array}{l}\text { I1-29Nov. } 1991 \text { CINDEFI- } \\
\text { Argentina }\end{array}$ & Dr. Osvaldo Yantorno \\
\hline $\begin{array}{l}\text { "Genetic Manipulation of Plants: } \\
\text { Transfer and Expression of } \\
\text { Foreign Genes" }\end{array}$ & $\begin{array}{l}\text { O4-16Nov. 1991 CEFOBI- } \\
\text { Argentina }\end{array}$ & Dr. Rubén Vallejos \\
\hline "Recombinant DNA Techniques" & $\begin{array}{l}\text { I11-27 Sept. 1991U.C.V - } \\
\text { Venezuela }\end{array}$ & Dr. Juan Carlos Mendible \\
\hline $\begin{array}{l}\text { "Second Advanced Course on } \\
\text { Biotechnological Processes" }\end{array}$ & $\begin{array}{l}\text { 07-25 October } 1991 \text { CEINGEBI- } \\
\text { UNAM México }\end{array}$ & Dr. Rodolfo Quintero \\
\hline "Food Biotechnology" & $\begin{array}{l}\text { 17-28February } 1992 \text { ICAITI - } \\
\text { Guatemala }\end{array}$ & Dr. Francisco Calzada \\
\hline "Molecular Basis of Diagnosis" & $\begin{array}{l}\text { 02-14February 1992I.V.I.C. - } \\
\text { Venezuela }\end{array}$ & Dr. Manuel Riber \\
\hline $\begin{array}{l}\text { "Third Advanced Training Course } \\
\text { on Industrial Scaling of } \\
\text { Biotechnological Processes" }\end{array}$ & $\begin{array}{l}\text { 12-230ctober } 1992 \text { CEINGEBI - } \\
\text { UNAM México }\end{array}$ & Dr. Rodolfo Quintero \\
\hline $\begin{array}{l}\text { "Plant Transformation of the Plant } \\
\text { Genetic Engineering" }\end{array}$ & $\begin{array}{l}\text { 03-05 October 1992 IPN - Irapuato } \\
\text {, México }\end{array}$ & Dr. Luis HerreraE. \\
\hline $\begin{array}{l}\text { First Workshop of the Diagnostics } \\
\text { and Vaccines Research N etwork }\end{array}$ & 15-17June 1992U.C.V - Venezuea & Dr.juan Carlos Mendible \\
\hline $\begin{array}{l}\text { "2nd Advanced course on } \\
\text { Recombinant DNA Techniques" }\end{array}$ & $\begin{array}{l}\text { 14Sep - 30ct. 1992U.C.V. - } \\
\text { Venezuela }\end{array}$ & Dr.Juan Carlos Mendible \\
\hline $\begin{array}{l}\text { "Analysis and Manipulation of the } \\
\text { Plant Genome" }\end{array}$ & $\begin{array}{l}\text { 13-27March 1993IPN - Irapuato, } \\
\text { México }\end{array}$ & Dr. Luis HerreraE. \\
\hline $\begin{array}{l}\text { "Immunology and Molecular } \\
\text { Genetics of Human and Animal } \\
\text { Retroviruses" }\end{array}$ & $\begin{array}{l}\text { 03-14May 1993I.V.I.C. - } \\
\text { Venezuela }\end{array}$ & Dr. Raúl Walder \\
\hline $\begin{array}{l}\text { "Biotechnology of Anaerobic } \\
\text { Treatment of Refuse" }\end{array}$ & $\begin{array}{l}\text { 16-24August.1993ICAITI - } \\
\text { Guatemala }\end{array}$ & Dr. Francisco Calzada \\
\hline $\begin{array}{l}\text { "Fourth Advanced Training } \\
\text { Course on Biotechnological } \\
\text { Processes" }\end{array}$ & $\begin{array}{l}\text { 11-22 October 1993CEINGEBI - } \\
\text { UNAM } \\
\text { México }\end{array}$ & Dr. Rodolfo Quintero \\
\hline
\end{tabular}




\begin{tabular}{|c|c|c|}
\hline $\begin{array}{l}\text { "Basic RecombinantDNA } \\
\text { Techniques and RFLP Course" }\end{array}$ & $\begin{array}{l}\text { 07-24September 1993U.C.V. - } \\
\text { Venezuela }\end{array}$ & Dr.Juan Carlos Mendible \\
\hline $\begin{array}{l}\text { "dentification, Mapping, } \\
\text { Expression and Regulation of } \\
\text { Plant Genes" }\end{array}$ & $\begin{array}{l}\text { 24-26Nov. 1993 Guaruja, Sao } \\
\text { Paulo Brazil }\end{array}$ & Dr. Ruben Vallejos \\
\hline $\begin{array}{l}\text { "Aplicaciones dela Biotecnologias } \\
\text { Modernas en la Agricultura" }\end{array}$ & $\begin{array}{l}\text { OI-2INOV. 1993INGEBI - } \\
\text { CONICET Buenos Aires - } \\
\text { Argentina }\end{array}$ & Dr. Alejandro Mentaberry \\
\hline $\begin{array}{l}\text { "Molecular Basis of Tumor } \\
\text { Growth Control, Differentiation } \\
\text { and Cell Cycle" }\end{array}$ & $\begin{array}{l}\text { 24Jan.- 6Feb. 19941.V.I.C - } \\
\text { Caracas Venezuela }\end{array}$ & Dr. Manued Rieber \\
\hline $\begin{array}{l}\text { "Application of Biotechnology for } \\
\text { Protection of Crops Against } \\
\text { Diseases and Pests" }\end{array}$ & $\begin{array}{l}\text { 03-140ctober 1994UNAM - } \\
\text { México }\end{array}$ & Dr. Rodolfo Quintero \\
\hline $\begin{array}{l}\text { "Basic Procedures for Antigen } \\
\text { Purification and Characterization } \\
\text { from Pathogenes: Mycobacterium } \\
\text { Tuberculosis y Leishmania sp." }\end{array}$ & $\begin{array}{l}\text { 09-21January 1995U.C.V. - } \\
\text { Venezuela }\end{array}$ & Dra. Fracehuli Dagger \\
\hline $\begin{array}{l}\text { "Molecular Growth of Tumor } \\
\text { Growth Control, Differentiation } \\
\text { and the Cell Cycle" }\end{array}$ & $\begin{array}{l}\text { 22 Jan.-3Feb. 1995I.V.I.C.- } \\
\text { Venezuela }\end{array}$ & Dr. Manue Rieber \\
\hline $\begin{array}{l}\text { "Analysis and Manipulation of the } \\
\text { Plant Genome" }\end{array}$ & $\begin{array}{l}\text { 12-25 March 1995IPN - Irapuato } \\
\text {-México }\end{array}$ & Dr. Luis HerreraE. \\
\hline $\begin{array}{l}\text { "Applications of New } \\
\text { Biotechnology's to A griculture" }\end{array}$ & $\begin{array}{l}\text { 15TMay 3June 1995 INTA - Moron } \\
\text { - Argentina }\end{array}$ & Dr. Alejandro Escandón \\
\hline $\begin{array}{l}\text { "Applications of Biotechnology to } \\
\text { Tuberculosis Research" }\end{array}$ & 12-15]une 1995 I.V.I.C. -Venezuela & Dr. Howard Takiff \\
\hline $\begin{array}{l}\text { "Application of Biotechnological } \\
\text { Processes" }\end{array}$ & $\begin{array}{l}\text { 09-200ctober 1995UNAM - } \\
\text { México }\end{array}$ & Dr. Rodolfo Quintero \\
\hline $\begin{array}{l}\text { "Biochemical Engineering } \\
\text { Applications in Environmental } \\
\text { Biotechnology and Cleaner } \\
\text { Production" }\end{array}$ & $\begin{array}{l}\text { 18-29September 1995ICAITI- } \\
\text { Guatemala }\end{array}$ & Dr. Francisco Calzada \\
\hline $\begin{array}{l}\text { "PolymerizeChain Reaction } \\
\text { (PCR), Differential Gene } \\
\text { Expression and DNA pplication in } \\
\text { Diagnosis" }\end{array}$ & $\begin{array}{l}\text { 21Jan.- 01Feb. 1996I.V.I.C. - } \\
\text { Venezuela }\end{array}$ & Dr. Manue Rieber \\
\hline $\begin{array}{l}\text { "Immunology and Molecular } \\
\text { Genetics of Human and Animal } \\
\text { Retroviruses: A spects of Viral } \\
\text { Diversity and I mmunopathology" }\end{array}$ & 08-19July 1996IVIC - Caracas & Dr. RaúlWalder \\
\hline $\begin{array}{l}\text { "Food and Environmental } \\
\text { Biotechnology" }\end{array}$ & 07-180ctober 1996 & $\begin{array}{l}\text { Dr. Rodolfo Quintero UNAM - } \\
\text { México }\end{array}$ \\
\hline $\begin{array}{l}\text { "Molecular Biology of } \\
\text { Tuberculosis" }\end{array}$ & $\begin{array}{l}\text { 16-31 October 1996INTA - Moron, } \\
\text { Argentina }\end{array}$ & Dr. Angel Cataldi \\
\hline $\begin{array}{l}\text { "Theoretical Practical aspects on } \\
\text { Epidemiology Diagnosis and } \\
\text { Vaccination on Brucellosis" }\end{array}$ & $\begin{array}{l}\text { 06-20January 19970niversidad } \\
\text { Austral deChile }\end{array}$ & Dra. Ximena Rojas \\
\hline $\begin{array}{l}\text { "PolymerizeChain Reaction } \\
\text { (PCR), Differential Gene } \\
\text { Expression DNA A pplication in } \\
\text { Diagnosis" }\end{array}$ & $\begin{array}{l}\text { 19-31January 1997I.V.I.C - } \\
\text { Venezuela }\end{array}$ & Dr. Manue Rieber \\
\hline $\begin{array}{l}\text { Analysis Manipulation of the } \\
\text { Plant Genome }\end{array}$ & $\begin{array}{l}\text { 10-21 March 1997CINVESTAV - } \\
\text { Mexico }\end{array}$ & Dr. Luis HerreraE. \\
\hline Environmental Biotechnology & $\begin{array}{l}\text { 30june-11July 19970NAM - } \\
\text { México }\end{array}$ & Dr. Rodolfo Quintero \\
\hline $\begin{array}{l}\text { Deveopments in Agro } \\
\text { Biotechnology }\end{array}$ & $\begin{array}{l}\text { O2-21 November 1997 INGEBI - } \\
\text { Buenos A ires Argentina }\end{array}$ & Dr. Alejandro Mentaberry \\
\hline $\begin{array}{l}\text { Expression of Antibody } \\
\text { Fragments in Bacteria as Fusion } \\
\text { Proteins in Bacteriophage: A } \\
\text { Theoretical-Practical Course }\end{array}$ & $\begin{array}{l}18-29 \text { November 1997CGEB - } \\
\text { Cuba }\end{array}$ & Dr.Jorge Gavilondo \\
\hline $\begin{array}{l}\text { TIInternational course on } \\
\text { Diagnosis of Tuberculosis }\end{array}$ & $\begin{array}{l}\text { 25Nov. 5Dec. 1997IPK - La } \\
\text { Habana - Cuba }\end{array}$ & Dr.JoséValdivia \\
\hline
\end{tabular}

UNU/ BIOLAC tries to select individuals particularly from key institutions in order to strengthen their capacities in the Program's priority areas. The fellowships are intended for individuals who already have a strong background in basic biological sciences, and have an advanced university degree, but who lack specific practical experience in biotechnological techniques.

The fellowships last for a minimum of three and a maximum of twelve months. UNU/BIOLAC provides a monthly 
stipend for the fellow, the round trip air ticket, travel accident and sickness insurance, and the eventual bench fees for the training institution.

Table 4 shows the total number of fellows benefited from UNU/ BIOLAC. A striking feature is that $62 \%$ of them are women. This suggests that, as opposed to long term academic fellowships, short-term training periods are considered by women as a positive step towards advancement

Table 4. Total number fellowships granted by UNU/ BIOLAC period 1990-97

\begin{tabular}{|l|l|}
\hline Women & 79 \\
\hline Men & 48 \\
\hline Total & 127 \\
\hline
\end{tabular}

The participation of women not only corresponds to the use of short-term training fellowships, they are also a very active and important part of the Networks. We are proud to say that the participation of women in the UNU/BIOLAC Program activities is as important as that of men.

Politics are not involved in the process of granting a fellowship. This is clear when we observe that countries with different political environments, such as Cuba and Peru with 21 and 24 fellowships respectively, have taken almost as much advantage of offered fellowships as Venezuela the host country, where 30 fellowships have been granted. The number of granted fellowships per country depends solely on the desire of the applicant and the human resource policy of each institute from which the postulants come from.

Only one fellowship has been granted to the English speaking Caribbean, Barbados. This suggests that, together with the possible language barrier, there is an old custom in the scientific community of those countries to train their scientists within the British Commonwealth, ignoring the possibilities that exists in Spanish speaking regions.

Keeping in mind that UNU/BIOLAC follows the same SOUTH-SOUTH cooperation framework of the University, we can observe in Table 5 that the new trend offered by the Program of training scientists for short periods of time within the region, has been accepted by all countries, developed or underdeveloped.

Table 6 shows the countries where training have taken place. Many of the granted fellowships have been used to learn new research techniques in those institutions where frontier science is made, while others have been employed to carry out collaborative projects in laboratories with which scientific linkages have become a reality. This means that one of the Program's objectives, to strengthen institutional capacities, has been fulfilled.

Table 5. Country of origin of fellows

\begin{tabular}{|c|c|c|c|c|c|}
\hline Argentina & 14 & Costa Rica & 4 & Peru & 24 \\
\hline Barbados & 1 & Cuba & 21 & Paraguay & 1 \\
\hline Bolivia & 5 & Chile & 6 & Rep. Dom. & 1 \\
\hline Brazil & 2 & Ecuador & 2 & Uruguay & 1 \\
\hline Colombia & 12 & Mexico & 3 & Venezuela & 30 \\
\hline
\end{tabular}

\section{Integration of human resources}

\section{Networks}

The University has in its charter the mandate to promote collaborative work among scientists in the developing world. As a result, the UNU/BIOLAC Program provides the infrastructure for Regional N etworks involving scientists and their laboratories in order to improve the contact and sharing of information among institutions in the region.

With the support of the Canadian Government, the UNU organized a Network of Researchers in Brucellosis which, after UNU/BIOLAC's creation in 1988, became part of the Program. This was so successful that in 1996 another Network of researchers was organized. This time the target was Tuberculosis. If funds are made available, we plan to organize a Network for each of the Program's concentration areas.

Both Networks, under the direction of a Scientific Coordinator, organize annual workshops for the members and a course in specific topics of the research interest of the Network. Members of the Networks execute collaborative research projects that in many cases are financed by international funding agencies. In addition the two research networks have an active network of electronic communication that interconnects its members and makes available recent relevant bibliographic information.

\section{The Brucellosis Research Network}

Brucellosis is a zoonosis that has become a public health problem in several countries in the region, whose economies have been affected by the appearance of the disease. In 1985 the Brucellosis N etwork was created through the initiative of The United Nations University, UNU, and with the support of Canadian Institutions such as the International Development and Research Center (IDRC), and the Government of Canada. When UNU/ BIOLAC was created, this network was incorporated into the activities of the Program.

The Network, as shown in Table 7, is formed by researchers from the region, and includes the United States and Canada. Its objectives include the improvement of diagnostic tools, the identification of candidate molecules for vacaines or diagnosis, and the development of mutant strains of Brucella abortus that might be evaluated in protection studies. 
Table 6. Country wheretraining took place

\begin{tabular}{|c|c|c|c|}
\hline Argentina & 5 & Chile & 10 \\
\hline Bolivia & 1 & France & 2 \\
\hline Brazil & 15 & Mexico & 49 \\
\hline Belgium & 1 & Peru & 1 \\
\hline Costa Rica & 1 & Venezuela & 31 \\
\hline Colombia & 7 & USA & 2 \\
\hline Cuba & 3 & & \\
\hline
\end{tabular}

The Brucellosis Network carries out a very active scientific program. The network has al ready published a book with the results of their first works and the publication of their second book is scheduled for the next future.

\section{The Tuberculosis Research Network}

Socio-economic changes occurring in recent years in Latin America and the Caribbean, with consequent diminished standards of living, have contributed to the resurgence of a disease that appeared to be on its way to eradication: tuberculosis. It is believed that a third of the worlds population is infected with Mycobacterium tuberculosis, leading to over 600,000 cases and 125,000 deaths per year in Latin America, and more than 3,000,000 deaths worldwide, mostly in developing countries. This disease, frequently associated with AIDS, has become increasingly dangerous because of the emergence of drug resistant strains.

The Tuberculosis Research Network, RELACTB, has the active collaboration of researchers from 12 countries of the region, as shown in Table 8. Invited scientists from Belgium, Canada, France, The Netherlands, Portugal, and Spain are also participating. This network studies the genetics and molecular biology of the mycobacterium, mechanisms of resistance, geographical distribution of strains within the region, use of techniques from molecular biology in diagnosis and development of simpler methods of cultivation in non-conventional mediums.

Table 7. Member countries of the brucel losis research network

\begin{tabular}{|c|c|}
\hline Argentina & Mexico \\
\hline Brazil & Peru \\
\hline Canada & Uruguay \\
\hline Colombia & USA \\
\hline Chile & Venezuela \\
\hline
\end{tabular}

With the support of UNU/ BIOLAC, RELACTB organizes advanced courses for young researchers, in order to disseminate new biotechnology for the study of this disease. It publishes an electronic bulletin, "RELACTBulletin" which describes the activities of its members.

\section{Final comments}

It is well known that the number of researchers in Latin America and the Caribbean is too small to cope with the needs of research and to successfully confront the number of short and long-term problems. In order to face these problems, the recommendations given are for the long run, and activities such as those carried out by UNU/BIOLAC play a very important role in the updating, recycling and permanent interchange of scientists in the region.

The Program has proven to be an important tool in preventing scientists from emigrating, as it allows the creation of new horizons for cooperative projects, thus producing favorable conditions for research.

In only seven years of work, the results produced by UNU/ BIOLAC support the hypothesis of a shared sense of direction within the region's scientific community. This, combined with the efforts of well established scientists in the region, is creating a new and stronger community which is working towards solving the problems of the current crisis and meeting the challenges of the near future.

This initiative demonstrates that entities such as UNU/BIOLAC, regardless of their limited financial resources, through their encouraging policy of supporting human resource improvement, can be successfully used by developing countries for their own benefit.

In order to guarantee the sustainability of scientific and technological developments in all countries of the region, it is important to encourage young scientists to strengthen their professional background. Therefore, it is desirable that other non-governmental organizations support efforts such as those made by UNU/ BIOLAC.

\section{Acknowledgments}

Thanks are due to Dr. A braham Besrat, Vice-Rector of UNU; to Dr. Jacobus de Waard, Dr. Luis Guevara, Associate Experts, Ad Hoc, to UNU/ BIOLAC, and Dr. Maria S. Tapia de Daza, for their help in the discussion, criticisms and suggestions; and to Mrs. Wilma James, Academic Officer Assistant at UNU for her support. 
Table 8. Member countries of the tuberculosis research network

\begin{tabular}{|l|l|l|}
\hline Argentina & Dominican Republic. & Belgium \\
\hline Bolivia & Honduras & Canada \\
\hline Brazil & Mexico & France \\
\hline Colombia & Nicaragua & The Netherlands \\
\hline Cuba & Peru & Portugal \\
\hline Chile & Venezuela & Spain \\
\hline
\end{tabular}

\section{References}

Annual Report (1989), (1990), (1991), (1992), (1993), (1994), (1995), (1996), and (1997). The United N ations University.

Training and Fellowship Programme Former Fellows Directory (1988-1992) and List of Training Workshop Participants (1983-1992). The United Nations University 